\title{
PLAGL1 Gene
}

National Cancer Institute

\section{Source}

National Cancer Institute. PLAGL1 Gene. NCI Thesaurus. Code C24680.

This gene plays an inhibitory role in the regulation of cellular proliferation and is a tumor suppressor. 